\title{
Językowe i tekstowe sposoby popularyzacji wiedzy prawnej w niemieckiej prasie opiniotwórczej i bulwarowej - pilotażowa analiza intralingwalna
}

\author{
Language and text related ways of popularisation of law in the German broadsheets and tabloids \\ - intralingual pilot analysis
}

\author{
Joanna WOŹNIAK \\ Uniwersytet im. Adama Mickiewicza w Poznaniu/ Adam Mickiewicz University \\ E-mail: woa@amu.edu.pl,
}

\begin{abstract}
The aim of the following paper is to present and discuss the issue of popularisation of specialised knowledge, in particular legal knowledge. For this purpose the author carried out a pilot analysis of selected articles from the German broadsheets and tabloids. The analysis is preceded by theoretical considerations of specialised knowledge, especially of legal knowledge, its transfer and popularisation in media. Then, the selected press articles were examined based on the techniques and strategies of popularisation described by Niederhauser. The analysis has shown that the techniques and strategies of popularisation of legal knowledge are different depending on the newspaper type. In particular, they differ in the field of content reduction and density, in the field of syntax and text structure, as well as aesthetics of visual materials.
\end{abstract}

Keywords: legal knowledge, intelligibility of legal texts, knowledge transfer, popularisation of law, techniques and strategies of popularisation, broadsheets, tabloids

\section{Wstęp}

Z powodu barier kognitywnych i technolektalnych idiolekt prawny bywa niezrozumiały dla części adresatów norm prawnych. Stąd też informacji o obowiązującym prawie laicy zwykle nie czerpią bezpośrednio z aktów normatywnych - eksponentów tejże wiedzy, - lecz z opracowań popularyzatorskich, w tym m.in. z artykułów prasowych. Dotychczasowe opracowania dotyczące środków tzw. rekontekstualizacji czy popularyzacji bazują na analizie materiałów popularnonaukowych, z prasy opiniotwórczej i/lub specjalistycznej. Celem niniejszego artykułu jest ukazanie, że analogiczne środki popularyzacji wiedzy specjalistycznej, takie jak redukcja treści, redukcja gęstości tekstu, odpowiedni sposób operowania terminami, uproszczona składnia, odpowiednia struktura tekstu, obrazy i wizualizacje, personalizacja etc., znajdują zastosowanie nie tylko w prasie specjalistycznej i opiniotwórczej, ale także w artykułach prasy bulwarowej. Przeprowadzona analiza pilotażowa ma ponadto wskazać płaszczyzny, na których uwidoczniają się różnice w zastosowaniu ww. technik i strategii w prasie opiniotwórczej i bulwarowej. Punkt wyjścia artykułu stanowią rozważania teoretyczne nad pojęciem wiedzy, jej transferencji oraz popularyzacji. 


\section{Wiedza specjalistyczna i jej transferencja oraz popularyzacja}

Wiedza to w rozumieniu teorii antropocentrycznej specyficzna właściwość wszystkich istot żywych. Nie jest ona bytem samoistnym, istnieje jedynie w połączeniu z konkretnym podmiotem i jego mózgiem (zob. S. Grucza 2013: 114). W oparciu o powyższe założenia terminem wiedza specjalistyczna określa się „konkretną wiedzę specjalistyczną istniejącą rzeczywiście w mózgu konkretnego specjalisty" (A. Bajerowska 2014: 236).

Wiedza składa się z subiektywnych założeń, teorii, intuicji i wniosków wytworzonych na podstawie studium literatury, doświadczenia czy eksperymentów. Wiedza stanowi więc wynik przetworzenia danych i informacji przez ludzką inteligencję (zob. D. Felbert 1998: 122).

G. Budin podkreśla, że konkretne informacje w systemie wiedzy są przekazywane zarówno poprzez tzw. „transfer wiedzy” (w procesach komunikacyjnych), jak i są wytwarzane bezpośrednio z obserwacji świata ożywionego i nieożywionego (zob. G. Budin 1996: 61 i nast.).

Określenie transfer wiedzy, rozpowszechnione m.in. w literaturze niemieckojęzycznej, krytykowane jest przez przedstawicieli teorii antropocentrycznej i zastępowane terminem transferencja. Słusznie wskazują oni, że podczas gdy określenie transfer odnosi się do prostej sytuacji <nadawca przekazuje - adresat przyjmuje>, termin transferencja rozumiany jest szerzej jako aktywny, kognitywny proces obejmujący sformułowanie tekstu, jego intencję i ostatecznie rekonstrukcję (zob. E. Hoher 2016: 7 i nast.). Transfer mylnie zakłada, że dana wiedza zostaje bezwarunkowo przekazana odbiorcy, podczas gdy „każdy człowiek sam generuje (rekonstruuje) własną wiedzę specjalistyczną pod wpływem określonych bodźców (np. tekstów specjalistycznych sformułowanych i zeksternalizowanych przez innych specjalistów - każdy specjalista tworzy swą wiedzę specjalistyczną w oparciu o idiowiedze specjalistyczne innych specjalistów)" (A. Bajerowska 2014: 33).

Pomimo różnic terminologicznych polscy i niemieccy naukowcy zdają się być zgodni co do wielowymiarowości procesu komunikowania wiedzy. Niemiecki socjo$\log$ B. Dewe wyróżnia termin transfer wiedzy jako określenie samej „oferty” wiedzącego dla adresata (bez określenia rezultatu) oraz termin transformacja wiedzy, czyli udany transfer wiedzy (zob. B. Dewe 1988). C. Weinreich (2010: 24) podkreśla natomiast, że transferencja wiedzy nie jest procesem odbywającym się $\mathrm{w}$ jednym kierunku, również ekspert (nadawca) bierze w nim udział, co może prowadzić do zmian w strukturze posiadanej przez niego wiedzy.

Transferencja wiedzy specjalistycznej może zachodzić zarówno w komunikacji wewnętrznej między specjalistami, jak i komunikacji typu specjalista - laik. Punkt ciężkości niniejszego artykułu skupiony jest wokół drugiego rodzaju komunikacji specjalistycznej, mianowicie wokół komunikacji między ekspertem a laikiem. Jej celem jest najogólniej rzecz biorąc chęć skutecznego przekazania odpowiedniej wiedzy fachowej partnerowi komunikacyjnemu, który tej wiedzy nie posiada lub posiada ją w stopniu niewystarczającym, lecz jej potrzebuje (świadomie bądź nie) (zob. D. Heller/ J. Engberg 2017: 119). Transferencja wiedzy odbywa się tutaj poprzez odpowiednio przygotowane teksty, tzw. teksty spopularyzowane, zaś sam pro- 
ces nazywany jest $\mathrm{w}$ literaturze popularyzacją.

Popularyzacja wiedzy specjalistycznej polega na przekazywaniu informacji specjalistycznych szerokiej opinii publicznej niebędącej ekspertem $\mathrm{w}$ danej dziedzinie. Popularyzacja to przede wszystkim specyficzny sposób produkcji tekstu (zob. J. Niederhauser 1997: 109, 1996: 42-60, także R. Gläser 1990: 179 i nast.). Tekstami spopularyzowanymi nazywana jest grupa rodzajów tekstów, ukierunkowana na przekazanie heterogenicznej grupie niespecjalistów informacji specjalistycznych w sposób komunikatywno-kognitywny, tak by zapobiec konfliktom komunikacyjnym. Autor tekstu musi zatem tak skonstruować tekst na płaszczyźnie strukturalno-funkcjonalnej, by umożliwiał on optymalną jego recepcję przez laika, to znaczy by umożliwił jego zrozumienie (zob. K.-D. Baumann 1998: 730). W procesie popularyzacji wiedzy specjalistycznej kluczową rolę odgrywa optymalizacja tekstu docelowego, czyli dostosowanie go na płaszczyźnie formy i treści do potrzeb i możliwości kognitywnych a także wiedzy początkowej adresatów (zob. S. Göpferisch 1998: 888).

D. Heller i J. Engberg (2017: 120) wskazują, że celem popularyzowania wiedzy specjalistycznej może być z jednej strony informowanie odbiorcy o pewnym fragmencie wiedzy specjalistycznej, rozszerzanie jego horyzontów z drugiej zaś strony zmodyfikowanie zachowania odbiorcy, skłonienie go do określonych działań, np. do podjęcia określonych decyzji (np. politycznych czy życiowych) lub do skorzystania z przysługujących mu praw.

\section{Popularyzacja wiedzy prawnej}

Szczególną dziedziną wiedzy, której popularyzacja jest pożądana w społeczeństwie, jest prawo. Ankieta przeprowadzona w latach 2008/2009 przez Towarzystwo Języka Niemieckiego (Gesellschaft für Deutsche Sprache) wykazała, że większość Niemców ma problemy ze zrozumieniem treści prawnych (zob. G. Antos/ H. Missal 2017: 330). Prawo dotyka w mniej lub bardziej bezpośredni sposób wszystkich obywateli. Niezastosowanie się do obowiązujących norm prawnych - bądź to celowe, bądź wynikające $\mathrm{z}$ ich niezrozumienia lub niewłaściwego zrozumienia - może wywrzeć negatywne skutki na życie obywatela. Zgodnie z rzymską maksymą Ignorantia iuris nocet to na obywatelu, a nie na prawodawcy spoczywa obowiązek zapoznania się z obowiązującym prawem. Niestety bariery kognitywne i technolektalne często nie pozwalają obywatelowi-laikowi na odpowiednie zrozumienie tekstu prawnego. Wykładnia przepisów prawnych przebiega bowiem nie tylko na podstawie kryteriów językowych (wykładnia językowa), ale także m.in. kryteriów uwzględniających cały system prawny (wykładnia systemowa), czy cel przyświecający ustawodawcy (wykładnia teleologiczna).

W literaturze wskazuje się na cztery zakresy umiejętności, które pozwolą odbiorcy norm prawnych na ich odpowiednie zrozumienie. Osoba taka winna: (1) posiadać kompetencję językową, a więc znać znaczenie wszystkich wyrazów zawartych w tekście prawnym, (2) znać reguły konstruowania norm prawnych i posiadać umiejętność rekonstruowania norm zawartych w tekście, (3) znać zasady wykładni norm prawnych, a więc reguły eliminowania wieloznaczności oraz nieostrości 
i wreszcie (4) znać reguły inferencyjne, które obejmują zastosowanie norm zarówno wyrażonych explicite, jak i tych, które jedynie wynikają z norm wyrażonych explicite (zob. T. Gizbert-Studnicki 1986: 110 i nast.). T. Gizbert-Studnicki wskazuje ponadto, że przed prawodawcą stawiane są często niezgodne lub nawet wykluczające się cele. „W szczególności postulat powszechnej zrozumiałości tekstów prawnych pozostaje $\mathrm{w}$ niezgodzie $\mathrm{z}$ dwoma innymi postulatami [...], a mianowicie postulatem zwięzłości i postulatem precyzji tekstów prawnych" (T. Gizbert-Studnicki 1986: 124). Zgodnie z Zasadami techniki prawodawczej (dalej jako ZTP) normy prawne „redaguje się zwięźle i syntetycznie, unikając nadmiernej szczegółowości” (§5 ZTP). Odrzucenie postulatu zwięzłości tekstu prawnego „mogłoby [...] prowadzić do całkowicie dowolnej interpretacji tekstu prawnego poprzez pomijanie dowolnych jego fragmentów jako redundantnych" (T. Gizbert-Studnicki 1986: 125). Z drugiej jednak strony ZTP nakazują, by przepisy redagowane były „tak, aby dokładnie i w sposób zrozumiały dla adresatów zawartych w nich norm wyrażały intencje prawodawcy" (§6 ZTP). Oba te postulaty trudne są do połączenia w jednym tekście prawnym.

Niemieckie wytyczne dotyczące zasad redagowania tekstów prawnych zawarte w Podręczniku techniki prawodawczej (Handbuch der Rechtsförmlichkeit) (dalej jako PTP) wydanym przez niemieckie Ministerstwo Sprawiedliwości również wskazują na konieczność zachowania równowagi między precyzją i jednoznacznością redagowanych norm a ich zrozumiałością i podają konkretne wskazówki redagowania tekstu prawnego. Prawodawca powinien formułować normy zwięźle (jedna norma w jednym zdaniu), unikać zdań złożonych, preferować styl werbalny i stosować krótkie słowa, unikać rozszerzonych przydawek i strony biernej, a także tzw. słówwypełniaczy, których użycie nic nie wnosi. Niemiecki prawodawca zdaje sobie jednak sprawę, że spełnienie postulatów zwięzłości, jednoznaczności i zrozumiałości nie zawsze jest możliwe $\mathrm{w}$ aktach prawnych. W PTP podkreśla on więc, że zrozumiałość aktu prawnego nie może odbywać się kosztem jego precyzji, dlatego też ewentualne deficyty zrozumiałości aktu prawnego mają być niwelowane m.in. poprzez broszury objaśniające, wskazówki publikowane na stronach internetowych czy też poprzez świadczenie usług doradczych przez urzędy państwowe (zob. PTP).

Taka zinstytucjonalizowana forma przekazywania obywatelom-laikom treści prawnych w sposób prosty i zrozumiały jest jedną z możliwości popularyzacji wiedzy prawnej. Inną mogą stanowić programy telewizyjne, audycje radiowe czy artykuły prasowe o charakterze popularyzatorskim.

\section{Popularyzacja treści prawnych w mediach}

Elementy wiedzy specjalistycznej występują w mediach w trzech postaciach, jako:

- audycje informujące o treściach specjalistycznych, które mają nieść ze sobą element rozrywkowy;

- tło wiedzowe w rubrykach i audycjach o charakterze rozrywkowym;

- poradniki dotyczące tych aspektów życia, które wymagają wiedzy specjalistycznej (zob. H. Burger / M. Luginbühl 2014: 362).

Przedmiotem rozważań niniejszego artykułu są teksty prasowe popularyzujące treści prawne i to im poświęcona zostanie dalsza część artykułu. 
Artykuły poradnikowe można zaliczyć za H.-H. Lügerem (1983: 92 też 2011: 150) do grupy tekstów instruktażowych. Ich celem jest dostarczanie informacji przyczyniających się do poprawienia stanu wiedzy adresatów lub uniknięcia przez nich negatywnych skutków deficytu tej wiedzy. Poradniki pomagają czytelnikowi zoptymalizować swoje zachowanie tak, by uniknąć nieprzyjemnych konsekwencji.

Artykuł poradnikowy definiowany jest w literaturze formalnie jako „1-3kolumnowa publikacja obejmująca tekst zasadniczy (złożony z nagłówka, lidu oraz wieloakapitowego spójnego korpusu), obudowany elementami dodatkowymi (ramki, miniporady, tabele, rekomendacje itp.) oraz grafiką (zdjęcia, rysunki, infografiki itp.)" (M. Worsowicz 2016: 88). Artykuły poradnikowe mogą przybierać formę wywiadu. W takim przypadku śródtytuły tekstu zawierają pytania, a kolejne jego części kilkuzdaniowe odpowiedzi (zob. M. Worsowicz 2016: 88).

Autorem artykułu poradnikowego jest zwykle dziennikarz wspierający się konsultacją eksperta bądź sam ekspert (zob. M. Worsowicz 2016: 88). Autor powinien posiadać solidnie ugruntowaną wiedzę specjalistyczną w danej dziedzinie, a w stosunku do adresata wykazywać przewagę w zakresie kompetencji interakcyjnych (zob. K.-D. Baumann 1998: 730). Czytelnicy artykułów popularyzujących wiedzę specjalistyczną to grupa heterogeniczna pod względem wieku, zainteresowań czy kompetencji (zob. K.-D. Baumann 1998: 730). W literaturze określa się ich mianem tzw. „general readers” (zob. R. Gläser 1990: 174).

W literaturze języko- i medioznawczej wymieniane są różne cele i funkcje dziennikarstwa poradnikowego. M. Worsowicz (2016: 86) wśród głównych funkcji dziennikarstwa poradnikowego wymienia funkcję informacyjną i doradczą, a także funkcję dydaktyczną, aktywizującą do samodzielnego działania, funkcję poprawy jakości życia poprzez formułowanie odpowiednich wskazówek, funkcję integrującą poprzez budowanie poczucia wspólnoty z osobami o podobnych problemach, funkcję propagandową oraz funkcję rozrywkową.

Artykuły popularyzatorskie zarówno w prasie specjalistycznej, jak i ogólnej nie tylko przekazują informacje fachowe, lecz przetwarzają je w sposób krytyczny i spełniają funkcję filtra tak, aby spreparowany tekst był dla czytelnika zrozumiały. W tym celu konieczne jest zastosowanie odpowiednich technik i strategii tekstowych oraz językowych.

\section{Techniki i strategie popularyzacji wiedzy specjalistycznej w prasie}

Podstawą zrozumiałego tekstu w ramach komunikacji specjalista - laik jest jego prostota, odpowiednia struktura, skrótowość i zwięzłość oraz odpowiednia zachęta względem czytelnika (zob. C. Weinreich 2010: 28). Skuteczne przekazywanie treści specjalistycznych laikom $\mathrm{w}$ danej dziedzinie $\mathrm{w}$ artykułach prasowych odbywa się poprzez adaptację skomplikowanych treści specjalistycznych do dotychczasowej wiedzy i możliwości poznawczych adresatów (zob. K.-D. Baumann 1998: 731). W tym celu autor dokonuje reorganizacji produkcji tekstu, a posługuje się przy tym konkretnymi środkami językowymi i retorycznymi. Środki te J. Niederhauser (1997: 111 i nast.) dzieli na techniki i strategie. Techniki transferencji dotyczą sposobów prezentowania i wyjaśniania informacji, podczas gdy strategie odnoszą się do tema- 
tyczno-treściowych sposobów realizacji danej informacji. Wśród technik popularyzacji J. Niederhauser (1997) wymienia: (1) redukcję treści, (2) redukcję gęstości tekstu, (3) odpowiedni sposób operowania terminami, (4) odpowiednią składnię i strukturę tekstu, (5) elementy aparatu naukowego, (6) obrazy i wizualizację. J. Niederhauser (1997: 118) zwraca uwagę, że w celu dotarcia do czytelnika-laika $\mathrm{z}$ informacją specjalistyczną rezygnuje się $\mathrm{w}$ prasie $\mathrm{z}$ mało atrakcyjnego stylu deskryptywno-argumentacyjnego. Zamiast tego stosuje się m.in. następujące strategie: (7) personalizację, (8) odniesienie do sytuacji dnia codziennego oraz (9) podkreślenie wagi i użyteczności poruszanych tematów. W dalszej części artykułu wszystkie wymienione strategie i techniki zostaną pokrótce objaśnione.

(1) Pod pojęciem redukcji treści J. Niederhauser (1997: 111) rozumie rezygnację z pewnych elementów treści lub elementów technicznych tekstu wyjściowego. Podczas transferencji treści specjalistycznych laikom przekazuje się jedynie wycinek informacji. $\mathrm{Z}$ jednej strony rezygnuje się $\mathrm{z}$ elementów technicznych, $\mathrm{np}$. $\mathrm{z}$ podawania konkretnych przepisów prawnych, tytułów aktów prawnych inter- i intratekstowych odsyłaczy itp. Z drugiej strony rzadko oddaje się pełen zakres tematyczny. Autor tekstu popularyzującego wybiera jedynie te treści, które jego zdaniem interesują czytelnika i są dla niego użyteczne (zob. J. Niederhauser 1997: 111). Jest to podyktowane wolą spełnienia oczekiwań czytelnika oraz ograniczonym miejscem na publikację danego artykułu.

(2) Przepisy ustawy redaguje się zwięźle i syntetycznie, unikając nadmiernej szczegółowości. W tekstach popularyzujących wiedzę wiele treści specjalistycznych jest uzupełnianych, opisywanych i rozszerzanych o kontekst tak, aby czytelnikom łatwiej było zrozumieć istotę problemu.

(3) Wymogi zwięzłości i syntetyczności realizowane są w przepisach prawnych głównie dzięki zastosowaniu odpowiednich terminów. Istotną cechą terminów jest ich jednoznaczność komunikacyjna, tj. posiadanie określonego znaczenia w danych, najczęściej specjalistycznym kontekście. Specjaliści potrafią przypisać to znaczenie terminowi wraz z innymi konotacjami systemowymi. Deficyt wiedzy specjalistycznej u laików jest zwykle kompensowany w tekstach popularyzujących unikaniem lub odpowiednim wyjaśnieniem terminu. Terminy są wyjaśniane kataforycznie, anaforycznie, są pomijane całkowicie lub zastępowane odpowiednikami z języka ogólnego.

(4) Artykuły popularyzujące wiedzę nie przejmują struktury i składni tekstów specjalistycznych, na których bazują. Struktura i składania tekstów prasowych uzależniona jest od gatunku prasowego i rodzaju prasy, a dokładniej rzecz ujmując od oczekiwań czytelnika/ grupy docelowej.

(5) Przez tzw. aparat naukowy J. Niederhauser (1997) rozumie bogate spisy literatury znajdujące się w tekstach naukowych, przypisy, odnośniki itp.

(6) Obrazy, grafiki i inne wizualizacje pełnią w tekstach specjalistycznych funkcję informacyjną, stanowią część wyjaśnienia danego zjawiska fachowego. Obrazy w tekście fachowym są podporządkowane treści, same w sobie nie stanowią informacji specjalistycznej, ich fachowość konstytuuje dopiero tekst, z którym obraz tworzy relację (zob. H. Kalverkämper 1993: 220 i nast.). W tekstach popularyzują- 
cych obrazy służą głównie przyciąganiu uwagi, poprawianiu atrakcyjności artykułu lub stanowią okazję do dyskusji nad danym tematem.

(7) Poprzez personalizację wskazuje się, że za konkretnymi osiągnięciami nauki lub problemami prawnymi stoją konkretne osoby. Czytelnik może się z tymi osobami utożsamiać. Dzięki personalizacji można także wprowadzić styl narracyjny, który ożywia tekst.

(8) Odnosząc określoną problematykę do czynności dnia codziennego łatwiej jest odbiorcy-laikowi zrozumieć skomplikowane, często abstrakcyjne, treści specjalistyczne.

(9) Częstym zabiegiem stosowanym w prasie jest wskazywanie na istotę danego problemu. Gazeta wyręcza w ten sposób czytelnika w decydowaniu, które informacje są dla niego użyteczne, a które nie. $Z$ punktu widzenia gazety strategia ta ma przykuć uwagę potencjalnego czytelnika i zwiększyć liczbę odbiorców.

Badania transferencji wiedzy specjalistycznej w materiałach popularyzujących zyskują $\mathrm{w}$ ostatnich latach na znaczeniu. W tym miejscy należy wymienić m.in. pracę E. Hoher (2016) poświęconą badaniu dyskursu prasowego o energii wiatrowej czy artykuł D. Heller i J. Engberga badających materiały informacyjne dla azylantów z zakresu prawa pobytu. Niedostatecznie zbadane pozostają jednak wciąż materiały popularyzujące wiedzę z obszaru prawa cywilnego, które od lat najbardziej wpływa na życie zwykłego obywatela. Umowy najmu, użyczenia, darowizny czy spadki to problemy, z którymi wcześniej czy później przyjdzie się zmierzyć niemal każdemu. Często jednym z podstawowych, a niekiedy nawet jedynym, źródłem czerpania informacji w tym zakresie jest prasa - ta tradycyjna papierowa a coraz częściej internetowa. W dalszej części artykułu wykorzystam środki wskazane przez J. Niederhausera (1997) w celu przeprowadzenia pilotażowej analizy artykułów poradnikowych z zakresu prawa spadkowego.

\section{Pilotażowa intralingwalna analiza porównawcza niemieckich artykułów poradnikowych z zakresu prawa spadkowego}

W literaturze niemieckiej prasę codzienną dzieli się ze względu na kryterium geograficzne na dzienniki regionalne i federalne oraz ze względu na kanał dystrybucyjny na dzienniki abonamentowe oraz sprzedażowe, które wskutek walki o uwagę potencjalnego klienta zmieniły się z czasem w dzienniki bulwarowe, tzw. tabloidy (zob. E. Straßner 1999: 18, H. Burger / M. Luginbühl 2014: 220 i nast.). W odróżnieniu od prasy opiniotwórczej w tabloidach dominuje znaczenie warstwy wizualnej kosztem werbalnej oraz zwiększona jest rola nagłówków (zob. M. Wojdyła 2011: 139). Język artykułów w prasie bulwarowej jest zwięzły, sensacyjny, emocjonalny, niekiedy wulgarny i naśladujący codzienną komunikację (zob. M. Conboy 2006: 14-15), zaś wyznacznikami ich stylu są: skandalizacja, personalizacja i uproszczenie aksjologii (zob. P. Golding/ S. McLachlan 2000: 78).

Analizie poddane zostały artykuły $\mathrm{z}$ wydań cyfrowych dwóch niemieckich dzienników o największym udziale w rynku: opiniotwórczego dziennika Süddeutsche Zeitung (dalej także jako SDZ) oraz tabloidu Bild (dalej także jako B).

Süddeutsche Zeitung to jeden $\mathrm{z}$ najlepiej sprzedających się krajowych dzienni- 
ków wydawany w Monachium, przez wielu dziennikarzy uważany za najbardziej opiniotwórczy dziennik w Niemczech. Paralelnie do wydania papierowego SDZ oferuje portal internetowy, w którym znaleźć można zarówno artykuły z wersji papierowych, jak i dodatkowe materiały redakcji. Głównymi czytelnikami wydania elektronicznego są osoby w wieku 20-29 lat, przeważnie z wyższym wykształceniem, zarabiające powyżej 3000 euro miesięcznie, zainteresowane polityką krajową i regionalną ${ }^{1}$.

Bild jest najlepiej sprzedającą się gazetą w Niemczech, oferującą poza wersją papierową także wersje cyfrowe swoich artykułów. Grupą docelową dziennika są głównie mężczyźni w wieku od 40 do 59 lat. 13\% czytelników to osoby z maturą lub wykształceniem wyższym. Ponad $60 \%$ to osoby aktywne zawodowo, głównie robotnicy lub wykwalifikowani robotnicy. Średni miesięczny dochód czytelnika dziennika Bild to od 1500 do 2500 euro' ${ }^{2}$.

Do analizy wybrane zostały po trzy artykuły z obu gazet. Artykuły dotyczą prawa spadkowego, a dokładniej zasad sporządzania testamentu. Treść artykułów dotyczy ogólnych zasad z zakresu dziedziczenia testamentowego, bez niuansowania problematyki. Artykuły były wyszukiwane każdorazowo na stronie wybranych gazet przy użyciu funkcji wyszukiwarki i wpisaniu odpowiednich słów kluczy: Testament, Erbe, Ratgeber, Recht. Do analizy wybrano po trzy najaktualniejsze artykuły spełniające ww. kryteria. Z SDZ wybrano następujące artykuły:

- „Sieben Tipps fürs Testament” $\mathrm{z}$ dnia 26.12.2016 autorstwa HermannaJosefa Tenhagena (w dalszej części artykułu jako SDZ1);

- „So vermeiden Sie Fehler im Testament” z dnia 08.02.2018 autorstwa Evy Dignös (w dalszej części artykułu jako SDZ2);

- „Wie ein Testament verfasst wird” z dnia 10.02.2018 autorstwa Evy Dignös (w dalszej części artykułu jako SDZ3).

Z dziennika Bild wybrano następujące artykuły:

- „Wie setze ich meinen letzten Willen durch?”, z dnia 15.08.2016, autor nieznany (w dalszej części artykułu jako B1);

- „Den letzten Willen richtig verfassen”, z dnia 06.01.2016, autor nieznany (w dalszej części artykułu jako B2);

- „Das wird beim Vererben oft falsch gemacht”, z dnia 05.04.2016, autorstwa Henrika Jeimke-Karge (w dalszej części artykułu jako B3).

Pierwszą różnicą między badanymi artykułami jest informacja o autorze. W artykułach z SDZ podanie autora zdaje się być nieodzownym elementem artykułu, w B odstępuje się od tej zasady. Przyczyny takiego stanu rzeczy upatrywać należy $\mathrm{w}$ istocie samej prasy. Prasa opiniotwórcza ma dostarczać wiarygodnych i rzetelnych informacji, czemu służy każdorazowe podanie autora. W prasie bulwarowej kwestie autorstwa artykułu często schodzą na drugi plan.

\footnotetext{
${ }^{1} \mathrm{http}: / /$ meedia.de/2012/12/05/analyse-der-typische-suddeutsche-de-leser/ [05.07.2018].

${ }^{2} \mathrm{http} / / /$ meedia.de/2013/01/24/analyse-der-typische-bild-leser/ [05.07.2018].
} 
a) Redukcja treści

Regulacje dotyczące prawa dziedziczenia znajdują się w księdze 5 niemieckiego kodeksu cywilnego (Bürgerliches Gesetzbuch, dalej jako BGB). Dział trzeci księgi piątej poświęcony jest testamentom. Podzielony jest on na 8 tytułów, w których znajduje się ponad 200 przepisów. Mimo że kryterium wyboru tekstów do analizy był ich wysoki poziom ogólności, wybrane artykuły jedynie w wąskim wymiarze pokrywają się ze sobą tematycznie. Oznacza to, że spośród 200 norm prawnych dotyczących testamentów autorzy 6 artykułów uznali różne normy za podstawowe, istotne i użyteczne dla czytelników. Jedynie cztery zagadnienia tematyczne, tzn. wymogi formalne w stosunku do spadkodawcy, forma testamentu odręcznego, przechowywanie testamentu oraz testament berliński, omawiane są w niemal wszystkich artykułach. W celu zapewnienia odpowiedniej płaszczyzny do porównania kolejnych elementów popularyzacji badanych tekstów, rozważania dalszej części artykułu będą się odnosiły głównie do czterech ww. tematów.

\begin{tabular}{|l|c|c|c|c|c|c|}
\hline & SDZ1 & SDZ2 & SDZ3 & B1 & B2 & B3 \\
\hline $\begin{array}{l}\text { wymogi formalne w } \\
\text { stosunku do spadkodawcy }\end{array}$ & & $\mathrm{X}$ & $\mathrm{X}$ & $\mathrm{X}$ & $\mathrm{X}$ & $\mathrm{X}$ \\
\hline forma testamentu odręcznego & $\mathrm{X}$ & $\mathrm{X}$ & $\mathrm{X}$ & $\mathrm{X}$ & $\mathrm{X}$ & $\mathrm{X}$ \\
\hline przechowanie testamentu & $\mathrm{X}$ & $\mathrm{X}$ & $\mathrm{X}$ & & $\mathrm{X}$ & \\
\hline testament berliński & $\mathrm{X}$ & & $\mathrm{X}$ & $\mathrm{X}$ & & $\mathrm{X}$ \\
\hline
\end{tabular}

Tabela 1. Zestawienie tematów poruszanych przez większość analizowanych artykułach.

$\mathrm{Na}$ wymienione w tabeli 1 zakresy tematyczne składają się konkretne normy prawne. I tak w odniesieniu do wymogów formalnych stawianych spadkodawcy z 2229 i 2247 BGB można odczytać następujące normy prawne:

- Prawo sporządzenia testamentu przysługuje osobom od 16 roku życia.

- W celu sporządzenia testamentu przez osobę niepełnoletnią nie jest potrzebna zgoda rodziców.

- Od sporządzającego testament oczekuje się pełnej świadomości dokonywanej czynności, czyli tzw. zdolności testowania (zdolności do dokonania rozrządzenia majątku).

- Prawo do sporządzenia testamentu własnoręcznego (nie notarialnego) przysługuje jedynie osobom pełnoletnim.

Wszystkie wymienione normy prawne zostały zrekonstruowane w artykułach B1 i B2. Po dokładnej analizie tekstów okazało się jednakże, że ten fragment obu artykułów jest identyczny, co wskazuje, że autor artykułu dokonał przedruku tekstu. Pozostałe analizowane artykuły zrekonstruowały jedynie po jednej z ww. norm. 


\begin{tabular}{|l|c|c|c|c|}
\hline & B1 = B2 & B3 & SDZ1 & SDZ2 \\
\hline testament odręczny od 18 roku życia & + & + & - & - \\
\hline testament notarialny od 16 roku życia & + & - & - & - \\
\hline $\begin{array}{l}\text { od 16 roku życia bez konieczności uzyskania } \\
\text { zgoda rodziców }\end{array}$ & + & - & - & - \\
\hline zdolność testowania & + & - & + & + \\
\hline
\end{tabular}

Tabela 2. Realizacja poszczególnych treści dla zagadnienia tematycznego , Wymogi formalne w stosunku do spadkodawcy".

Podobne zróżnicowanie w rekonstrukcji konkretnych norm prawnych zauważyć można w przypadku innych zagadnień tematycznych:

\begin{tabular}{|l|c|c|c|c|c|}
\hline & B1 = B2 & B3 & SDZ1 & SDZ2 & SDZ3 \\
\hline podział na odręczny i notarialny & - & + & + & + & - \\
\hline $\begin{array}{l}\text { pisany własnoręcznie (osobiście i } \\
\text { bezpośrednio) }\end{array}$ & + & - & + & + & + \\
\hline $\begin{array}{l}\text { elementy oświadczenia woli (data i } \\
\text { miejsce sporządzenia) }\end{array}$ & $\begin{array}{l}+/- \text { (brak } \\
\text { miejsca) }\end{array}$ & - & - & + & - \\
\hline podpis (imię i nazwisko) & + & - & + & + & - \\
\hline procedura w przypadku wątpliwości & + & - & - & + & - \\
\hline
\end{tabular}

Tabela 3. Realizacja poszczególnych treści dla zagadnienia tematycznego „Forma testamentu”.

\begin{tabular}{|l|c|c|c|c|}
\hline & B1 & B3 & SDZ1 & SDZ3 \\
\hline sporządzany przez małżonków & + & + & + & + \\
\hline forma & - & - & - & + \\
\hline wzajemne dziedziczenie & + & - & + & - \\
\hline $\begin{array}{l}\text { nieważność testamentu w przypadku } \\
\text { rozwodu }\end{array}$ & - & - & - & - \\
\hline $\begin{array}{l}\text { brak możliwości zmiany po śmierci } \\
\text { jednego z małżonków }\end{array}$ & $+/-$ & + & - & - \\
\hline
\end{tabular}

Tabela 4 Realizacja poszczególnych treści dla zagadnienia tematycznego „, Testament berliński”.

W przypadku przechowywania testamentu autorzy artykułów wyszli ponad regulacje BGB. W artykułach SDZ1-SDZ3 oraz B1 poza samym prawem do złożenia testamentu do depozytu wymieniono konkretne instytucje prowadzące depozyty, orientacyjny koszt i formalne wymogi złożenia testamentu do depozytu. 


\begin{tabular}{|l|c|c|c|c|c|c|}
\hline & B1 & B2 & B3 & SDZ1 & SDZ2 & SDZ3 \\
\hline prawo złożenia do depozytu & + & + & + & + & + & + \\
\hline $\begin{array}{l}\text { dodatkowe informacje: jaka instytucja, } \\
\text { koszt, wymogi formalne }\end{array}$ & + & - & - & + & + & + \\
\hline
\end{tabular}

Tabela 5. Realizacja poszczególnych treści dla zagadnienia tematycznego „Przechowywanie testamentu”.

Powyższe zestawienia nie dają jednoznacznej odpowiedzi na pytanie, czy analizowane artykuły z prasy opiniotwórczej i tabloidowej różnią się $\mathrm{w}$ zakresie redukowania rekonstruowanej wiedzy dotyczącej testamentów, choć z powyższych tabel można przypuszczać, że artykuły w dzienniku Bild poruszają więcej zagadnień niż w SDZ. Należałoby jednak sprawdzić, czy w ślad za liczbą poruszonych zagadnień idzie ich należyte (a nie jedynie pobieżne) wyjaśnienie. W tym celu analizie poddano gęstość tekstu.

b) Redukcja gęstości tekstu

W odróżnieniu od przepisów BGB, które zostały zredagowane w sposób syntetyczny, zwięzły, nie wykraczający poza jedno zdanie, zagadnienia w artykułach prasowych obu gazet rozszerzone są o kontekst czy podkreślenie wagi bądź użyteczności danego rozwiązania dla czytelnika (zob. J. Niederhauser 1997: 111 i nast.).

Przykład 1.

Ein nach $\$ 2247$ errichtetes Testament ist auf Verlangen des Erblassers in besondere amtliche Verwahrung zu nehmen. (BGB)

$\mathrm{Z}$ przytoczonego fragmentu ustawy wynikają następujące informacje:
Co?
Co należy zrobić?
Testament własnoręczny
Kiedy?
Oddać do depozytu urzędowego.
Jeśli spadkodawca będzie sobie tego życzył.

Viele Testamente verschwinden, weil sie dem Finder nicht gefallen. Deshalb gehört der letzte Wille nicht zu Hause in die Schublade, sondern sollte an einem sicheren Ort verwahrt werden. (B3)

Natomiast z artykułu prasowego czytelnik uzyskuje poniższe informacje:

Co?

Co się z nimi dzieje?

Dlaczego znikają?

Co jest złym rozwiązaniem?

Co należy zrobić?

\section{Testamenty.}

Znikają.

Są niewygodne dla spadkodawców.

Chowanie testamentu w domu/w szufladzie.

Oddać testament do depozytu.

Przykład 2.

Der Erblasser kann ein Testament durch eine eigenhändig geschriebene und unterschriebene Erklärung errichten. (BGB) 
Z przytoczonego fragmentu ustawy wynikają następujące informacje:

Kto? Spadkodawca.

Co może zrobić? Sporządzić testament.

W jaki sposób? Własnoręcznie spisując i podpisując oświadczenie woli.

Kein Computer, keine Schreibmaschine: Wer sein Testament selbst, ohne Hilfe eines Notars, verfasst, muss es vom ersten bis zum letzten Wort mit der Hand schreiben. Nur dann ist es gültig [...]. Ein ausgedruckter Text mit Unterschrift genügt nicht. Der Grund: Gibt es Zweifel an der Echtheit des Testaments, kann ein Schriftgutachter feststellen, ob es wirklich vom Erblasser geschrieben wurde. (SDZ3)

$\mathrm{Z}$ artykułu prasowego czytelnik uzyskuje poniższe informacje:

Kto?

Co musi zrobić?

Co nie może być użyte?

Dlaczego?

Dlaczego odręcznie?
Ten, kto chce napisać testament (spadkodawca).

Spisać testament odręcznie.

Komputer lub maszyna do pisania.

Ponieważ wtedy testament będzie nieważny. $\mathrm{W}$ przypadku wątpliwości testament może zostać poddany analizie grafologa.

Z powyższego wynika, że w artykułach obu badanych dzienników gęstość tekstu wyjściowego ( $w$ tym przypadku ustawy) jest redukowana poprzez odpowiednie strategie: dodatkowy opis, przywołanie konkretnych sytuacji dnia codziennego, odniesienie do powodów i celów itp. Różnice między artykułami z prasy opiniotwórczej odnoszą się do długości tych opisów. Sprowadzając badane artykuły do liczby zdań i słów przypadających statystycznie na dane zagadnienie tematyczne w poszczególnych artykułach uzyskano następujące wyniki:

- SDZ1 - 116 słów/ 9 zdań na jedno zagadnienie tematyczne;

- SDZ2 - 119 słów/ 8 zdań na jedno zagadnienie tematyczne;

- SDZ3 - 173 słowa/ 11 zdań na jedno zagadnienie tematyczne;

- B1 - 76 słów/ 6 zdań na jedno zagadnienie tematyczne;

- B2 - 72 słowa/ 8 zdań na jedno zagadnienie tematyczne;

- B3 - 93 słowa/ 6 zdań na jedno zagadnienie tematyczne.

Statystycznie artykuły w Süddeutsche Zeitung stosują więc więcej zdań i więcej słów w celu omówienia danego zagadnienia tematycznego niż artykuły w Bild. Można by zatem postawić hipotezę, że tabloidy bardziej skrótowo opisują określone zagadnienia tematyczne niż prasa opiniotwórcza. Są to jednak wyniki czysto statystyczne i należy je zweryfikować pogłębianą analizą jakościową.

c) Sposób operowania terminami

Istotę ważnych dla laika zagadnień prawnych trudno oddać bez używania podstawowych terminów prawnych. $\mathrm{Z}$ uwagi na rolę, jaką prawo odgrywa w życiu człowieka część terminów prawnych przeniknęła do języka ogólnego (choć nie zawsze są one należycie rozumiane i używane przez laików). Również w analizowanych artykułach nie odstąpiono od stosowania terminów. Ich liczba jest porównywalna $\mathrm{w}$ artykułach $\mathrm{z}$ obu rodzajów prasy. Użyte terminy to terminy podstawowe dla regu- 
lacji dotyczących testamentu. Są to m.in. terminy: Erblasser, Willenserklärung, gesetzlicher Vertreter, Amtsgericht, Notar, eigenhändiges Testament, Testierabsicht, Testamentsregister, letzter Wille, Nachlassgericht (w dzienniku Bild), czy Testierfähigkeit, privatrechtliches Testament, notarielles Testament, BGB, Schriftgutachter, letzter Wille, Vermächtnis, Erbschaftssteuer, Schenkung (w SDZ). Trudno dyskutować o problematyce dziedziczenia przez testament bez posługiwania się nimi.

Niemniej niemal wszystkie $\mathrm{z}$ powyższych terminów zostały odpowiednio wkomponowane $\mathrm{w}$ tekst. Część z nich została wyjaśniona kataforycznie lub anaforycznie lub poprzez podanie synonimów czy wyjaśnienia w nawiasie.

Viele warten zu lange mit ihrem Testament. So kann man z.B. nach einem Unfall oder

Schlaganfall nicht dazu in der Lage (nicht mehr testierfähig) sein. (B3)

Voraussetzung für ein gültiges Testament ist die Testierfähigkeit. "Ob sie noch gegeben war, wenn der Erblasser beispielsweise an Alzheimer erkrankt war, ist oft Anlass für Streit zwischen den Erben", sagt Jan Bittler. (SDZ2)

Niekiedy w artykułach rezygnowano z terminów i zastępowano je określeniem ogólnym. W poniższym przykładzie posłużono się wyrazem ogólnym Eltern/ rodzi$c e$, podczas gdy BGB stosuje $\mathrm{w}$ tym miejscu termin szerszy gesetzlicher Vertreter/ przedstawiciel ustawowy.

Mit Hilfe eines Notars darf auch ein 16-Jähriger sein Testament machen - ohne Zustimmung der Eltern. (B1 i B2)

Artykuły w wersji cyfrowej mają przewagę w stosunku do artykułów w wersji papierowej i nie muszą uwzględniać wszystkiego w jednym tekście. Oferują użytkownikom nowe możliwości. Zasada hipertekstu umożliwia zdefiniowanie danego pojęcia w nowym oknie (zob. E. Straßner 2000: 20). Większość analizowanych artykułów stosuje hiperlinki i odsyła do innych tekstów, w których dane zagadnienie bądź dany termin został dokładnie objaśniony.

Denn ein Vermächtnis ist etwas anderes als eine Erbschaft (mehr zu Vermächtnissen lesen sie hier). (SDZ3)

W zakresie stosowania terminów analizowane artykuły obu rodzajów prasy nie wykazują większych różnic.

d) Struktura tekstu i składnia

W odniesieniu do płaszczyzny strukturalnej artykułów prasowych wśród elementów pozytywnie wpływających na odbiór tekstu wymienia się: podział na części, użycie czcionek o różnych rozmiarach i typach, podkreślenia, zróżnicowany kolor, wielkość interlinii oraz wszelkiego rodzaju inne ornamenty graficzne (zob. E. Straßner 2000: 18). Cechy te w dużym stopniu reprezentowane są w analizowanych artykułach. Artykuły w SDZ podzielone są na części. W każdej części omawiane jest inne zagadnienie tematyczne. Każda część ma formę linearnego spójnego tekstu. Poszczególne części artykułu w SDZ są wydzielone dość subtelnie poprzez pogrubione śródtytuły. Czcionka śródtytułów jest wielkości czcionki tekstu. 
Artykuły B1 i B2 mają formę wywiadu. Każde nowe zagadnienie tematyczne wprowadzone jest poprzez pytanie (potencjalne, które zadaje sobie czytelnik), poniżej znajduje się odpowiedź na to pytanie. Pytania oddzielające poszczególne zakresy tematyczne są scentrowane, pogrubione i zaznaczone większą czcionką niż tekst odpowiedzi. Taka forma ma przyciągnąć uwagę czytelnika i nakierować go na konkretne problemy.

\begin{abstract}
1. Testament handschriftlich verfassen: Viele vertrauen darauf, dass das Bürgerliche Gesetzbuch schon das Nötige regelt. Und in vielen Fällen sind die Regelungen zur gesetzlichen Erbfolge gar nicht so verkehrt. Aber oft passen sie heute nicht mehr, insbesondere wenn der Erblasser neben der Familie auch einen Lebensgefährten, Stief- und Patenkinder oder Freunde bedenken will. Patchwork-Familien sind in der gesetzlichen Erbfolge nicht vorgesehen. Wer wirklich den liebsten Menschen Vermögen hinterlassen möchte, der muss ein Testament machen. Wichtig: Das Testament muss unbedingt in Gänze handschriftlich verfasst sein.
\end{abstract}

Rysunek 1. Uktad tekstu sktadowego w SDZ1.

\title{
Darf jeder ein Testament schreiben?
}

Nein. Wer unzurechnungsfähig oder nicht geschäftsfähig ist, darf das nicht. Die sogenannte Testierfähigkeit muss gegeben sein.

Der Erblasser muss volljährig und geschäftsfähig sein - er muss erkennen können, was seine Willenserklärung bedeutet. Mit Hilfe eines Notars darf auch ein 16-Jähriger sein Testament machen - ohne Zustimmung der Eltern.

Rysunek 2. Uktad tekstu sktadowego w B1.

Długość zdań i ich nasycenie rozbudowanymi wyrazami są głównymi elementami decydującymi o zrozumiałości tekstu. Narzędzie do zbadania indeksu czytelności tekstu oferuje Instytut Psychometrica. Udostępniony przez Instytut kalkulator oblicza współczynnik jasności tekstu na podstawie liczby zdań i ich długości. Współczynnik ten wskazuje na złożoność danego tekstu. I tak:

- $\quad$ teksty o współczynniku poniżej 40 - są na poziomie literatury dziecięcej i młodzieżowej;

- teksty o współczynniku 40-50 - są na poziomie beletrystyki;

- teksty o współczynniku 50-60 - są na poziomie literatury rzeczowej;

- teksty o współczynniku powyżej 60 - są na poziomie literatury fachowej ${ }^{3}$.

\footnotetext{
${ }^{3}$ http://www.psychometrica.de/lix.html [05.07.2018].
} 
Po poddaniu badanych artykułów analizie w udostępnionym przez Psychometricę kalkulatorze otrzymano następujące wyniki:

\begin{tabular}{|c|c|c|c|c|c|}
\hline Liczba słów & Liczba zdań & $\begin{array}{l}\text { Średnia dłu- } \\
\text { gość zdania }\end{array}$ & $\begin{array}{l}\text { Udział dłu- } \\
\text { gich słów w } \\
\text { tekście }\end{array}$ & $\begin{array}{l}\text { Indeks czytel- } \\
\text { ności }\end{array}$ & $\begin{array}{l}\text { Złożoność } \\
\text { tekstu }\end{array}$ \\
\hline \multicolumn{6}{|c|}{ Sieben Tipps fürs Testament (SDZ1) } \\
\hline 700 & 54 & 12,9 & 32,4 & 45,3 & średnia \\
\hline \multicolumn{6}{|c|}{ So vermeiden Sie Fehler im Testament (SDZ2) } \\
\hline 477 & 32 & 14,9 & 34,5 & 49,4 & średnia \\
\hline \multicolumn{6}{|c|}{ Wie ein Testament verfasst wird (SDZ3) } \\
\hline 867 & 54 & 16 & 33,2 & 49,2 & średnia \\
\hline \multicolumn{6}{|c|}{ Wie setze ich meinen letzten Willen durch? (B1) } \\
\hline 1970 & 146 & 13,4 & 34,6 & 48,1 & średnia \\
\hline \multicolumn{6}{|c|}{ Den letzten Willen richtig verfassen (B2) } \\
\hline 845 & 69 & 12,2 & 31,9 & 44,1 & niska \\
\hline \multicolumn{6}{|c|}{ Das wird beim Vererben oft falsch gemacht (B3) } \\
\hline 362 & 42 & 8,6 & 33,4 & 42 & niska \\
\hline
\end{tabular}

Tabela 6. Wyniki badania indeksu czytelności analizowanych tekstów (http://www.psychometrica.de/lix.html).

W odniesieniu do badanych akapitów obejmujących 4 zagadnienia tematyczne wspólne dla wszystkich artykułów teksty w SDZ wykazują większą złożoność składniową niż teksty w Bild. Zdania w SDZ są bardziej rozbudowane. Ich czytelność jest na poziomie średnim, tak jak utwory beletrystyczne, jednak zbliżającym się do poziomu literatury rzeczowej.

- SDZ1: 20 zdań, 12 złożonych 3 wielokrotnie, udział zdań złożonych w tekście $60 \%$;

- SDZ2: 13 zdań, 7 złożonych, 4 wielokrotnie, udział zdań złożonych w tekście 53\%;

- SDZ3: 27 zdań, 11 złożonych, 4 wielokrotnie, udział zdań złożonych w tekście $40 \%$.

Artykuły w Bild mają mniej złożoną strukturę składniową, ich zrozumiałość jest na poziomie beletrystyki, zbliżającym się jednak do literatury dziecięcej i młodzieżowej. Analiza poszczególnych fragmentów tekstów wykazała, że na płaszczyźnie składniowej dominują zdania proste.

- B1: 34 zdania, 15 złożonych 3 wielokrotnie, udział zdań złożonych w tekście $44 \%$;

- B2: 19 zdań, 6 złożonych, 2 wielokrotnie, udział zdań złożonych w tekście $31 \%$;

- B3: 11 zdań, 3 złożone, udział zdań złożonych w tekście 27\%. 
e) Elementy aparatu naukowego

W tekstach prawnych elementami aparatu naukowego są oznaczenia poszczególnych jednostek redakcyjnych wyższego i niższego stopnia czy odwołania wewnątrztekstowe. Natomiast w tekstach prawniczych, takich jak wyroki czy komentarze stosuje się odwołania do literatury, uwagi czy wtrącenia. Zarówno jednych, jak i drugich brak jest w analizowanych poradnikach. Dla czytelnika-laika liczy się esencja, norma, która obowiązuje, a nie to, jak ta norma umiejscowiona jest w całym systemie prawnym czy doktrynie prawnej.

f) Obrazy i wizualizacje

Obrazy zastosowane $\mathrm{w}$ analizowanych artykułach pełnią funkcję estetyczną, mają również przyciągnąć uwagę czytelnika. Umiejscowione są na początku artykułu.

Występują we wszystkich artykułach w SDZ i tylko w jednym artykule w Bild. Estetyka obrazów w SDZ jest inna niż w Bild. W SDZ obraz - odręcznie napisane piórem słowo Testament - podkreśla istotę i powagę problemu, odwołuje się do autorytetu notariusza. Obraz w B1 - zwinięte w rulonik banknoty euro - odwołuje się do wartości materialnych, odpowiedniego zarządzania pieniądzem.

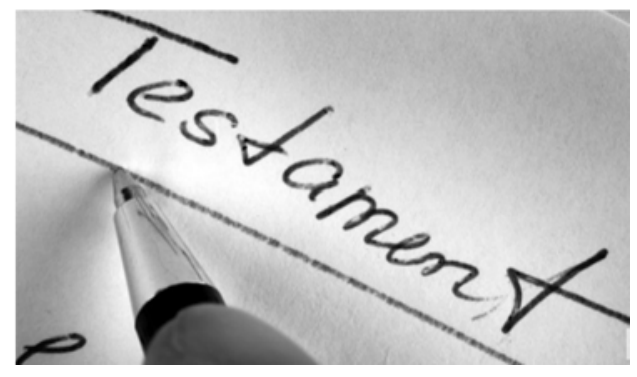

Rysunek 3. Obraz w artykule SDZ3.

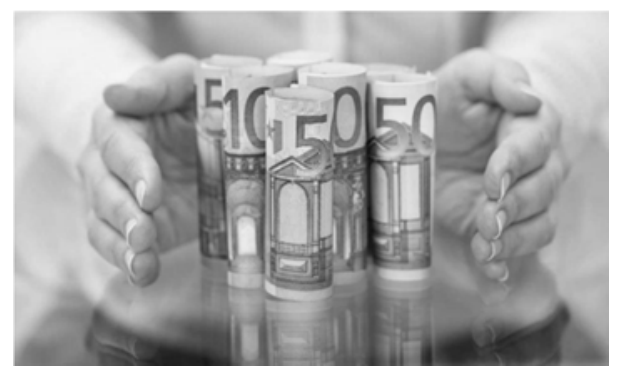

Rysunek 4. Obraz w artykule B1.

\section{g) Personalizacja}

Przykład personalizacji znaleźć można w artykule B2. Na początku artykułu znajduje się odwołanie do wywiadu, którego dziennikowi Bild udzielił aktor Klaus Behrendt. Przyznaje on, że sporządził już swój testament, aby nie pozostawiać swojej rodziny z trudnymi wyborami.

Klaus J. Behrendt (56) verriet in einem BILD-Interview, dass er sein Testament bereits gemacht habe. Denn der „Tatort“-Kommissar möchte seine Frau und Kinder nach seinem Tod mit schwierigen Entscheidungen nicht allein lassen. (B2)

h) Podkreślenie istoty i wagi problemu

Wskazanie na wagę problemu, jakim jest sporządzanie testamentu, zamieszczane jest na początku analizowanych artykułów. Autorzy wskazują bezpośrednio, że jest to ważki temat lub kreślą negatywne w skutkach konsekwencje braku testamentu, których potencjalny spadkodawca może uniknąć spisując testament.

Keiner denkt gern über den Ernstfall nach. Dennoch ist es wichtig: Was soll eigentlich später einmal mit dem Haus passieren? Wer soll erben - und wie viel? Und wer kümmert sich, wenn ältere Angehörige ins Krankenhaus müssen? (SDZ1) 
Jedoch ohne Testament tritt die gesetzliche Erbfolge ein, und da kann es durchaus passieren, dass die Witwe aus dem gemeinsamen Haus ausziehen muss. Wer dies seinen Lieben ersparen möchte, setzt seinen Letzten Willen in ein Testament um. (B2)

i) Odniesienie do sytuacji dnia codziennego

W celu ułatwienia czytelnikom recepcji tekstu autorzy artykułów obu dzienników starają się przedstawić skomplikowane treści prawne w sposób skonkretyzowany, odwołując się do rzeczywistych sytuacji, które mogą wystąpić.

Viele warten zu lange mit ihrem Testament. So kann man z.B. nach einem Unfall oder Schlaganfall nicht dazu in der Lage (nicht mehr testierfähig) sein. (B3)

\section{Podsumowanie i wnioski}

Przeprowadzona pilotażowa analiza artykułów poradnikowych z zakresu sporządzania testamentów opublikowanych w niemieckich dziennikach Süddeutsche Zeitung oraz Bild wykazała, że większość środków i technik popularyzacji wiedzy specjalistycznej wykorzystywanych $\mathrm{w}$ materiałach popularnonaukowych znajduje zastosowanie także w tekstach prasy ogólnej, zarówno opiniotwórczej jak i bulwarowej. Różnice w zastosowaniu tych środków ujawniają się głównie na płaszczyźnie redukcji treści i redukcji gęstości tekstu, składni i struktury tekstu oraz estetyki materiałów wizualnych. Teksty w artykułach prasy bulwarowej zdają się poruszać więcej zagadnień tematycznych, ale w sposób bardziej pobieżny. Ponadto teksty w Bild wykazują mniej skomplikowaną składnię, wyraźniej zróżnicowaną strukturę tekstu i formę, zmniejszającą dystans między czytelnikiem a prasą, a także wykorzystywane są w nich bardziej ekspresywne obrazy, często bazujące na emocjach czytelników.

Przeprowadzona analiza objęła zaledwie 6 artykułów z danego zakresu tematycznego. Powyższe wnioski nie mają tym samym charakteru ogólnego, stanowią jedynie punkt wyjścia do dalszych badań. Analizę należy poszerzyć zarówno o kolejne artykuły z zakresu prawa dziedziczenia testamentowego, jak i innych zagadnień prawa cywilnego oraz o inne tytuły prasy opiniotwórczej i bulwarowej. Niniejszy artykuł i opisane w nim badania wstępne potwierdziły, że dalsza analiza artykułów poradnikowych w prasie codziennej jest zasadna. Należy jednak podkreślić, że przyszłe badania powinny zostać pogłębione o bardziej szczegółowe zagadnienia z zakresu strukturyzacji tekstu, rutyny tekstu, argumentacji i morfoskładni.

\section{Bibliografia}

Antos, G. / H. Missal (2017), Rechtsverständlichkeit in der Sprachkritik der Öffentlichkeit, (w:) E. Felder/ F. Vogel (red.), Sprache und Recht. Berlin/ Boston, 329346.

Bajerowska, A. (2014), Transferencja wiedzy specjalistycznej. Warszawa.

Baumann, K.-D. (1998), Fachsprachliche Phänomene in den verschiedenen Sorten der populärwissenschaftlichen Vermittlungstexte, (w:) L. Hoffmann/ H. Kalverkämper/ E. Wiegand/ Ch. Galinski/ W. Hüllen (red.), Fachsprachen/ 
Languages for Special Purposes. Halbband 1. Berlin/ New York, 717-728.

Budin, G. (1996), Wissensorganisation und Terminologie. Tübingen.

Burger, H./ M. Luginbühl (2014), Mediensprache. Eine Einführung in Sprache und Kommunikationsformen der Massenmedien. Berlin/ Boston.

Conboy M. (2006), Tabloid Britain. Constructing a Community through Language. London/ New York.

Dewe, B. (1988), Wissensverwendung in der Fort- und Weiterbildung. Zur Transformation wissenschafticher Informationen in Praxisdeutungen. Baden-Baden.

Felbert, D. v. (1998), Wissensmanagement in der unternehmerischen Praxis, (w:) P. Pawlowsky (red.), Wissensmanagement: Erfahrungen und Perspektiven. Wiesbaden, 119-141.

Gizbert-Studnicki T. (1986), Język prawny z perspektywy socjolingwistycznej. Kraków. Gläser, R.(1990), Fachtextsorten im Englischen. Tübingen.

Golding P./ S. McLachlan (2000), Tabloidization in the British press: A quantitative investigation into changes in British newspapers, 1952-1997, (w:) C. Sparks (red.), Tabloid Tales. Oxford, 75-89.

Göpferisch, S. (1998), Möglichkeiten der Optimierung von Fachtexten, (w:) L. Hoffmann/ H. Kalverkämper/ E. Wiegand/ Ch. Galinski/ W. Hüllen (red.), Fachsprachen/Languages for Special Purposes. Halbband 1. Berlin/ New York, 888-899.

Grucza, S. (2013), Lingwistyka języków specjalistycznych. Warszawa.

Heller, D./ J. Engberg (2017), Sprachliche Verfahren der Popularisierung von Rechtswissen. Zur Rekontextualisierung asylrechtlicher Grundbegriffe, (w:) „Trans-kom” 10 [1], 1-21.

Hoher, E. (2016), Fachwissentransferenz im öffentlichen Diskurs. Warszawa.

Kalverkämper, H. (1993), Das fachliche Bild. Zeichenprozesse in der Darstellung wissenschaftlicher Ergebnisse, (w:) H. Schröder (red.), Fachtextpragmatik. Tübingen, 215-238.

Lüger, H.-H. (1983). Pressesprache. Tübingen.

Niederhauser, J. (1996), Wissenschaftliche Fachsprache und populärwissenschaftliche Vermittlung. Linguistische Untersuchungen zur fachexternen Wissenschaftskommunikation. Bern.

Niederhauser, J. (1997), Das Schreiben populärwissenschaftlicher Texte als Transfer wissenschaftlicher Texte, (w:) E.-M. Jakobs/ D. Knorr (red.), Schreiben in den Wissenschaften. Frankfurt/ Main, 107-122.

Straßner, E. (1999), Zeitung. Tübingen.

Straßner, E. (2000), Journalistische Texte. Tübingen.

Weinreich, C. (2010), Das Textsortenspektrum im fachinternen Wissenstransfer. Untersuchung anhand von Fachzeitschriften der Medizin. Berlin/ New York.

Wojdyła, M. (2011), Wybrane wyznaczniki stylu tabloidów (na podstawie pierwszych stron gazet), (w:) I. Kamińska-Szmaj/ T. Piekot/ M. Poprawa (red.), Tabloidy. Język, wartości, obraz świata. Wrocław, 139-150.

Worsowicz, M. (2016), Stylistyczne uwikłania artykułu poradnikowego (na przykładzie ogólnotematycznej prasy poradnikowej dla kobiet), (w:) „Acta Universi- 
tatits Lodziensis. Folia Litteraria Polonica” 2 (32), 85-93.

\section{Źródla prawne}

$\mathrm{BGB}=$ Bürgerliches Gesetzbuch (niemiecki kodeks cywilny) w wersji z dnia ogłoszenia tekstu jednolitego 2 stycznia 2002. (https://www.gesetze-iminternet.de/bgb/). [Pobrano 22.08.2018].

Handbuch der Rechtsförmlichkeit. Empfehlungen zur Gestaltung von Gesetzen und Rechtsverordnungen herausgegeben von Bundesministerium der Justiz (http://hdr.bmj.de/vorwort.html). [Pobrano 22.08.2018].

ZTP $($ Zasady Techniki Prawodawczej $)=$ Rozporządzenie Prezesa Rady Ministrów z dnia 20 czerwca 2002 r. w sprawie „Zasad techniki prawodawczej” (Dz.U. $2002 \mathrm{nr} 100$ poz. 908). 